\title{
Evaluation of concrete blocks reinforced with bamboo fibers treated with $\mathrm{NaOH}$
}

Cassiano Rodrigues Moura cassiano.moura@ifsc.edu.br Instituto Federal de Santa Catarina (IFSC), Jaraguá do Sul, SC, Brasil

Luiz Veriano Oliveira Dalla Valentina

luiz.valentina@udesc.br

Universidade do Estado de Santa

Catarina (UDESC), Joinville, SC, Brasil

Adalberto José Tavares Vieira adalberto.vieira@udesc.br

Universidade do Estado de Santa

Catarina (UDESC), Joinville, SC, Brasil

\author{
ABSTRACT
}

This paper presents the research of the influence of chemical treatment with sodium hydroxide $(\mathrm{NaOH})$ applied on bamboo fibers, to be used as concrete blocks reinforcement. The objective is to analyze the influence of the fibers on the mechanical properties of the cement composite. The research methodology used in this paper is of literary and experimental disposition, while the investigated plant belong to the species Bambusa Vulgarise, which passed through chemical treatment with $\mathrm{NaOH}$. Later, the fibers were characterized by optical microscopy and SEM. The characterization of the composite material was performed with bending tests. The results show the contribution of the reinforcement provided by treated fibers on the tensile strength during the bending of the concrete blocks, which evidence the importance to apply the chemical treatment. The study show that it is possible to use the treated bamboo fiber as a viable alternative on concrete blocks reinforcement, with superior resistance when compared to those of the bamboo in-natural.
\end{abstract}

KEYWORDS: Bamboo fiber. Chemical treatment. Concrete block. $\mathrm{NaOH}$. 


\section{INTRODUCTION}

The global awareness about high energy consumption and consequent higher levels of pollution, have been increasing the number of academic researches about construction materials from natural sources, which could substitute industrialized products used on civil construction. One of the essential materials of civil construction is the steel, which is used in concrete composites acting as reinforcement for several structures. The cost of this material is one preponderant factor, as the scarcity of the mineral resources used on its manufacturing makes its price increasingly high.

According to Liu et al. (2012) the natural vegetal fibers have contributed in a positive way for the economic prosperity and the sustainability of many regions. Specifically, the bamboo fiber, which have been used for industrial applications as textile processes, pulp and paper industries and civil construction.

Bamboo is a plant that presents similar potentialities as steel, being used as alternative construction elements and, due to its lower cost, can minimize the problem of manufacturing costs. The use of bamboo fiber has been explored as a material with significant potential for structural applications (GHAVAMI e BARBOSA, 2007). Bamboo has specific weight approximately ten times lower than that of steel. In average, this property of the bamboo varies from $800 \mathrm{~kg} / \mathrm{m}^{3}$ to $950 \mathrm{~kg} / \mathrm{m}^{3}$ while steel has in average $7800 \mathrm{~kg} / \mathrm{m}^{3}$.

On the engineering field, bamboo presents characteristics of mechanical resistance of high interest for application on composite materials. Once the specific resistance of bamboo fibers is comparable to that of the steel (YU et al., 2013; LIU et al., 2012).

The basic structure of bamboo fibers is composed by hemicellulose, cellulose, lignin, beyond other constituents with lower percentage such as pectin, inorganic salts, nitrogen substances and natural colorings (PHILIPP e D'ALMEIDA, 1998). Among these constituents, the content of cellulose is the main responsible for the resistance and stiffness of the natural fibers. The increase of concentration of this component, can improve the fibers properties for mechanical resistance.

Generally, the natural fibers are used in natura, however some researchers have studied techniques to improve the conditions of these materials, mainly to be used in composites. Alkaline treatments based on sodium hydroxide $(\mathrm{NaOH})$ are recurrently used for this means, removing hemicellulose and lignin, thus increasing the cellulose content (JÄHN et al., 2002; TRUJILLO et al., 2010; DAS e CHACRABORTY, 2008; KUMAR et al., 2010; LIU et al., 2010).

According to Jähn et al. (2002), chemical treatment on natural fibers, performed with sodium hydroxide $(\mathrm{NaOH})$ based solutions, contributes to increase the cellulose content, once this solution removes hemicellulose. So that, contributing to increase the resistance and stiffness of the fiber, improving the increase on the composite resistance.

Different authors have been studying applications with bamboo for distinct objectives, among them as reinforcement for several kinds of matrices. Kongkeaw et at. (2011) used bamboo fibers of the species Thyrsostachys Siamensis Gamble to prepare composites in a matrix of epoxy resin with a fiber 
content of $20 \%$ randomly distributed to increase the mechanical properties of the material. On his studies Li et al. (2015) researched the wettability of bamboo laminates of the species Phylostachys Pubescens to manufacture plates of laminated bamboo with phenol-formaldehyde. In order to improve the mechanical properties of the bamboo interface and its applications, bamboo was thermally treated on oil at $180^{\circ} \mathrm{C}$ during 2 hours.

Xie et al. (2015) investigated cement based composites reinforced with cellulose fibers, specifically rice straw and bamboo. The fiber percentage varied from $2 \%$ up to $16 \%$ in weight. The results of the composite materials showed an improvement on the mechanical properties when compared with the sample without the fibers reinforcement. Measuring showed that the flexural strength can be increased in $24,3 \%$ and the fracture strength up to 45 times.

Sharma (2015) investigated the mechanical properties of two kinds of products commercially available: bamboo scrimber and laminated layers of bamboo. Later, he compared them with standard wooden engineering materials. The results showed that the bamboo products have properties equal or higher to the wood and wooden based products.

Ghavami (1995) studied the adherence between bamboo and concrete. He determined that their interface can be seen as a negligible thickness zone, responsible for the adhesion of the materials. Ghavami and Marinho (2005) presented test results of pullout tests performed with parts of bamboo impregnated with epoxy resin based structural adhesive, and reached values of $2,75 \mathrm{Mpa}$. As a comparison, steel presents values of 3,25Mpa.

\section{OBJECTIVES}

This work studied the use of bamboo fiber, extracted through chemical treatment with $\mathrm{NaOH}$ for partial removal of hemicellulose and lignin existent on the plant. Such procedure allowed the separation and individualization of the fibers, maximizing the cellulose content.

The objective of the present study is to determinate the influence of the chemical processing applied on the bamboo fibers, on the mechanical properties of tensile and flexural strength in application as reinforcement of concrete blocks.

\section{MATERIALS AND METHODS}

\section{MATERIALS}

- The bamboo species used in this work was Bambusa Vulgarise, the plant was supplied by Enville enterprise, located on the region of Joinville/SC (BRAZIL);

- For the chemical treatment process, it was used sodium hydroxide $(\mathrm{NaOH})$ in scales;

- For the concrete development it was used Portland cement CPII Z-32, sand, gravel and water, with dosing in volume of $1 ; 3 ; 3 ; 0,56$. 


\section{EXPERIMENTAL METHODS}

The methodological experimental procedure used for this research is presented on Figure 1.

Figure 1 - Methodological experimental procedure

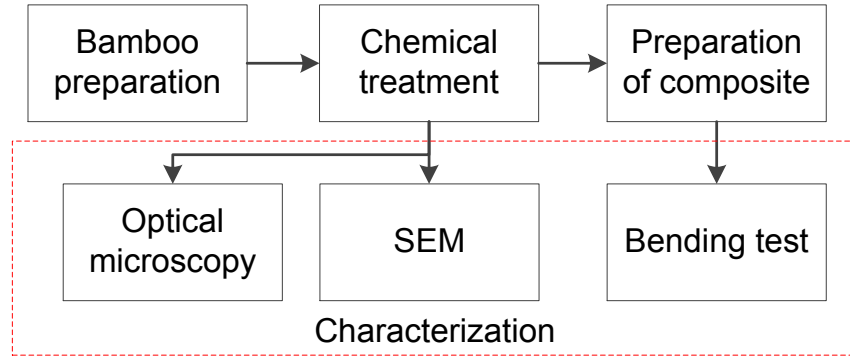

Source: Own authorship (2017)

\section{Bamboo Preparation}

The plant was picked with the age of approximately 5 years, average interval where it presents higher resistance on the stem. As showed on Fig. 2, it was used the third internode for the experimental analysis, due to the changes on the mechanical properties along the stems disposal.

Subsequently, the stems were cut in pieces, measured and kiln dried at the temperature of $100^{\circ} \mathrm{C}$, for a time enough for the humidity loss to be $0,5 \%$.

Figure 2 - Stem selection

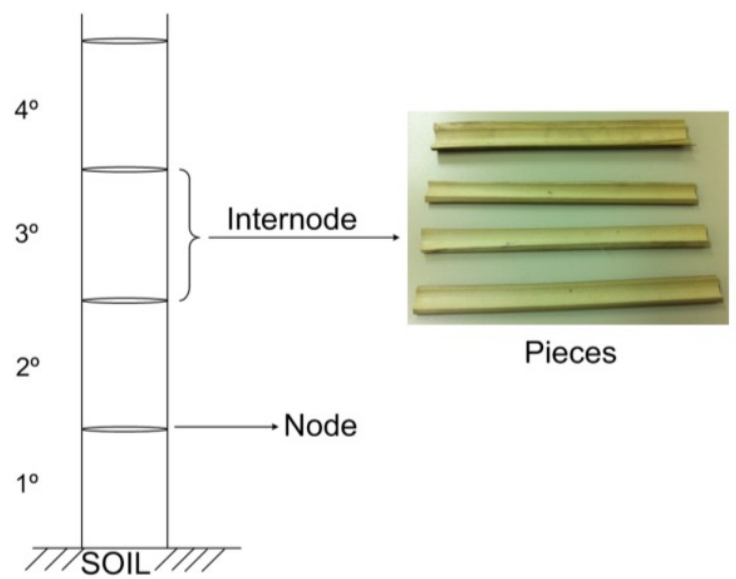

Source: Own authorship (2017)

The humidity percentage was monitored hourly, until the moment the mass variations were lower than $0,5 \%$, what was considered negligible. The material was then cooled down to ambient temperature. The percentage calculation for the humidity content $(\mathrm{m})$ was performed through Equation 1.

$m(\%)=\frac{m_{i}-m_{f}}{m_{i}} x \mathbf{1 0 0}$ 
Where:

- $\boldsymbol{m}$ is the content of percentage humidity (g);

- $\boldsymbol{m}_{\boldsymbol{i}}$ is the initial mass $(\mathrm{g})$;

- $\boldsymbol{m}_{\boldsymbol{f}}$ is the loss of mass after an interval of time $(\mathrm{g})$.

\section{Chemical Treatment}

Chemical treatment was applied on the bamboo strips in order to maximize the cellulose content, solubilizing the hemicellulose and lignin. Such procedure enabled the removal of these extracts, contributing for the partial separation of the fibers and maximizing the mechanical properties.

Another contribution of this work was that, traces of $\mathrm{NaOH}$ which were impregnated on the fibers wall acted as a barrier for a possible attack of insects and bacteria, once they could quickly deteriorate this material.

A solution of $\mathrm{NaOH}$ (sodium hydroxide) was prepared with a concentration of $13,5 \% \mathrm{~m} / \mathrm{m}$ where the bamboo pieces were submerse during $14 \mathrm{~h}$. After the time stipulated by the experiment, the strips were removed from the solution and calendered by metal rolls with $1 \mathrm{~mm}$ spacing in order to remove the excess of $\mathrm{NaOH}$ and to individualize the fibers. Later, the fibers were kiln dried at a temperature of $100^{\circ} \mathrm{C}$ for 5 hours. The Figure 3 presents the appearance of the fibers during the chemical treatment process.

Figure 3 - Appearance of the fibers on the beginning of the chemical treatment (a); during the treatment (b); after the drying process (c) and after the individualization of the fibers (d)

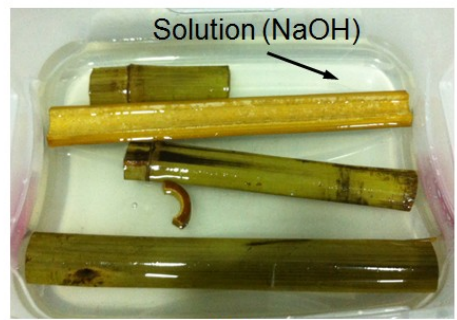

(a)

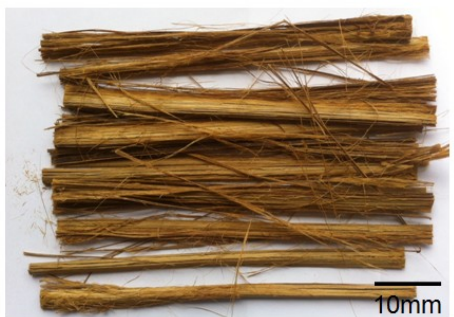

(c)

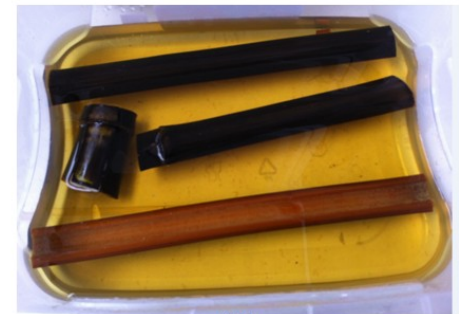

(b)

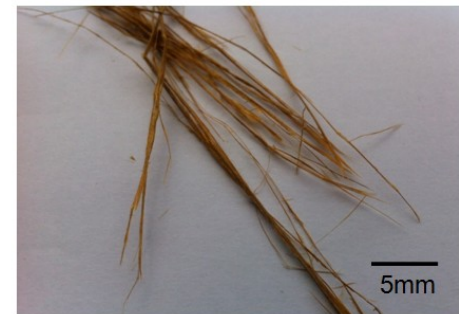

(d)

Source: Own authorship (2017)

\section{Preparation of Composite}

The concrete molding process was performed on metallic molds with 
were manually thickened with help of a metallic rod. The cure time was performed by wetting, the blocks were placed on a sand mattress covered by towels. The wetting was performed once a day during 28 days, when it was performed the bending test.

Four concrete blocks were prepared, according to Table 1 . The reinforcements applied were centrally placed on the cross-section of the blocks according to Figure 4 . The block 1 was prepared with pure concrete, without reinforcements. On the block 2 it was used one CG-50 steel rebar with ribbed surface and of the brand Gerdau (one of the most common of the market), with rated diameter of $6,3 \mathrm{~mm}$, rated mass $0,245 \mathrm{~kg} / \mathrm{m}$ and resistance limit of $1,08 \mathrm{MPa}$. The block 3 was reinforcing with bamboo in-natural (without treatment).

Table 1 - Characteristics of the specimens for bending

\begin{tabular}{ccc} 
Block & Type of reinforcement & Characteristics \\
1 & Without reinforcement & Simple concrete \\
2 & Steel & Rebar of $\varnothing 6,3 \mathrm{~mm}$ \\
3 & Bamboo in-natural & Two strips of $7 \times 15 \mathrm{~mm}$ each \\
4 & Bamboo fiber & Chemically treated - bundle with $\varnothing 12 \mathrm{~mm}$ \\
\hline
\end{tabular}

Source: Own authorship (2017)

Figure 4 - Scheme used for reinforcement application - cross-section
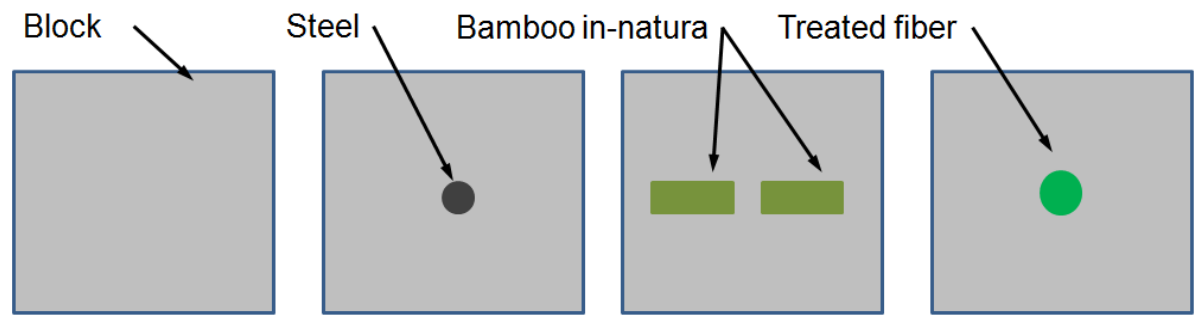

Source: Own authorship (2017)

On the block 4, it was used a fiber bundle chemically treated with $\mathrm{NaOH}$ with cross-section diameter of $12 \mathrm{~mm}$. The beam was tied using a nylon line with diameter of $0,20 \mathrm{~mm}$. This procedure was adopted in order to increase the packing factor, as shown of Figure 5.

Figure 5 - Fiber bundle after tying, (a) fiber bundle, (b) cross-section

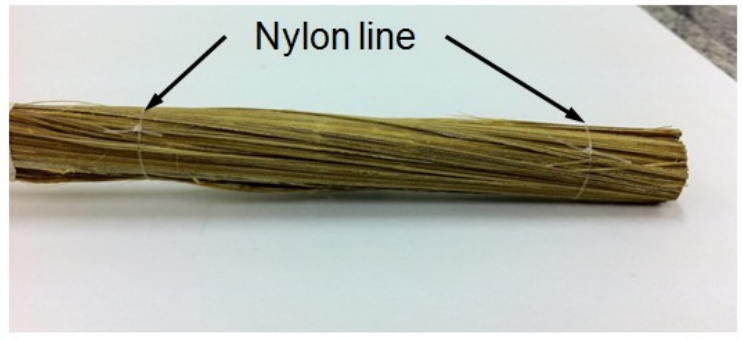

(a)

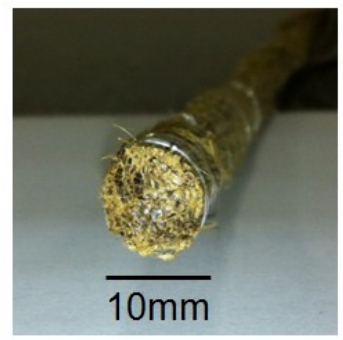

(b)

Source: Own authorship (2017) 


\section{Characterization by Optical Microscopy}

The microscopy analysis was performed by an optical microscope brand Olympus CX31.

\section{Characterization by Scanning Electron Microscopy - SEM}

To evaluate the impregnation of $\mathrm{NaOH}$, the fibers walls were analyzed by the scanning electron microscope (SEM), brand Jeol JSM - 6701 F, with coupled X ray detector. Also, it was performed a chemical analysis through Energy-Dispersive XRay Spectrometry.

\section{Bending Test}

Later, tensile strength and bending tests were performed over 4 supports, on the 28th day after the blocks molding according to the specification of the Standard NBR 12142 (2010), the load cell used was $2 \mathrm{kN}$ rated, and the speed of loading was $1,5 \mathrm{~mm} / \mathrm{min}$. The obtained results were the tensile strength on the flexure and the construction of the curve applied force by time. The blocks were placed on the equipment with help of a square and a scale. They were later placed on the superior supports and it was started the test procedure, according to Figure 6.

Figure 6 - Positioning of the concrete block for bending test

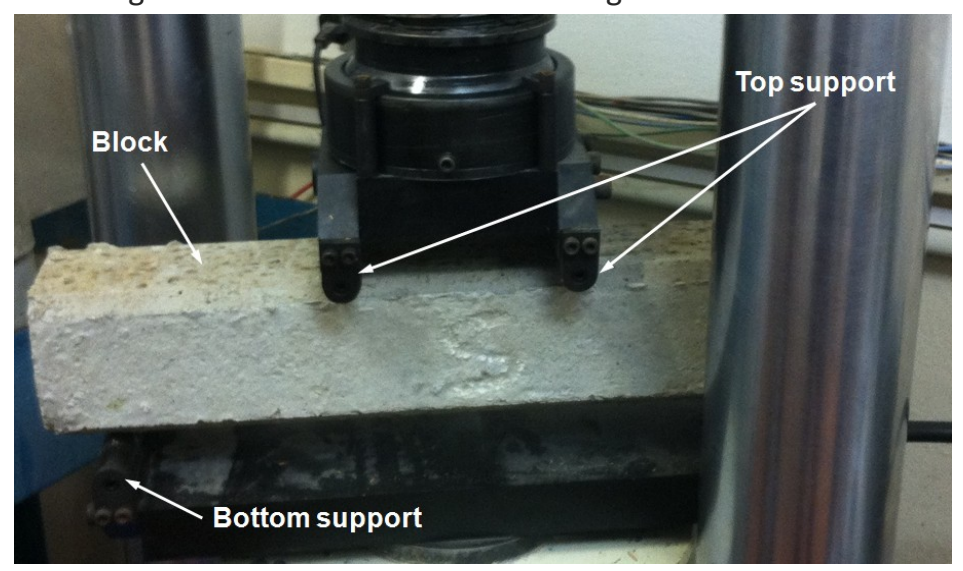

Source: Own authorship (2017).

The tensile strength on the bending was calculated according to Equation 2.

$f_{c t M}=\frac{p x l}{b x d^{2}}$

(2)

Where:

$f_{c t M}$ is the tensile strength on the bending (MPa);

$\mathbf{p}$ is the maximum applied load $(\mathrm{N})$;

$l^{l}$ is the distance between support bottoms $(\mathrm{mm})$; 
b is the average width of the specimen, at the rupture section (mm);

d is the average height of the specimen, at the rupture section $(\mathrm{mm})$.

\section{RESULTS AND DISCUSSION}

\section{BAMBOO PREPARATION}

The technical detailing and the information regarding the plant used on this research are presented on Table 2 .

Table 2 - Technical information of the plant

\begin{tabular}{cc} 
Bamboo & Characteristics \\
Species & Bambusa Vulgarise \\
Age & 5 years \\
Height & $18 \mathrm{~m}$ \\
Technical data of the internode & Characteristics \\
Average wall thickness & $6,22 \mathrm{~mm}$ \\
Average diameter & $48,95 \mathrm{~mm}$ \\
Average lenght & $476 \mathrm{~mm}$ \\
\hline
\end{tabular}

Source: Own authorship (2017)

With the application of the drying process it was possible to obtain a drying curve, as shown on Figure 7, which presents the bets conditions for the fibers to be submitted to. It can be observed that on the initial drying stage it occurs a high loss of mass, due to the high amount of liquid contained on the stems.

It can be observed on Figure 7 that from approximately 14h, the drying process reaches a linear level, turning the loss of mass to an almost negligible level. The loss of humidity in this moment is $0,1 \%$ in average, it means very close to zero, as shown on Figure 48.

Figure 7 - Drying curve of the bamboo fibers

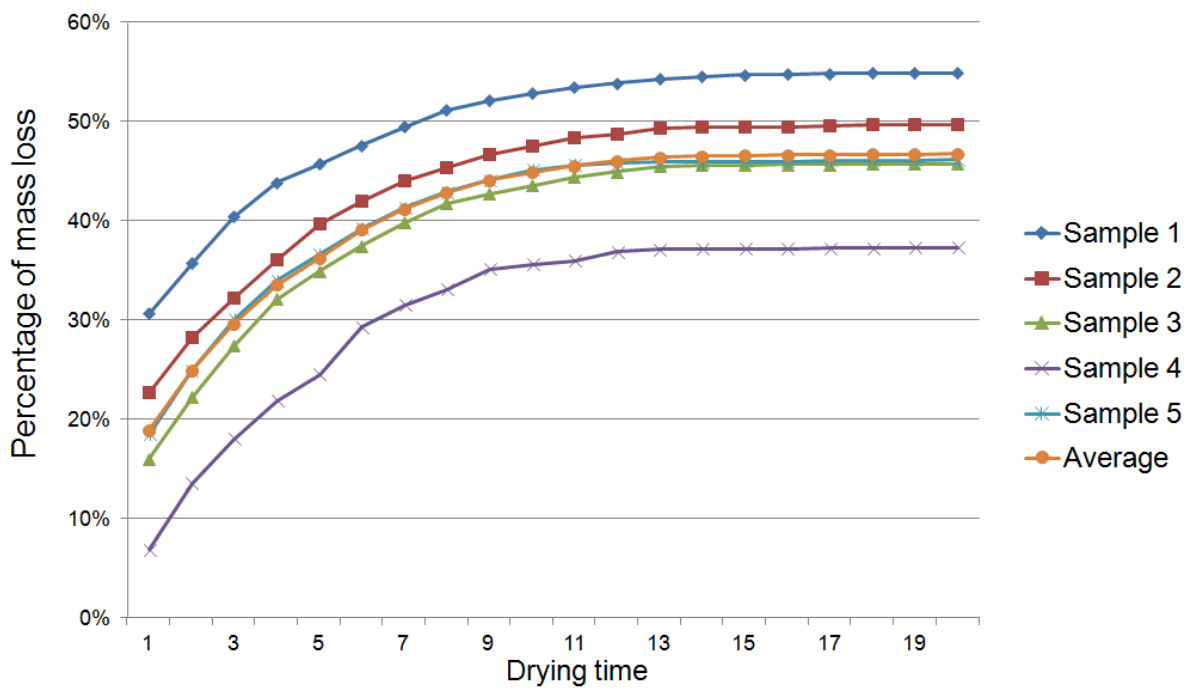

Source: Own authorship (2017). 


\section{CHEMICAL TREATMENT}

With the application of chemical treatment it was possible to calculate the percentage loss of mass, which is the factor of removal of hemicellulose and lignin present on the wall fibers.

The Figure 8 presents the results, considering the sum of treatment times of 5, 10 and 15 hours for treatment with $\mathrm{NaOH}$.

Figure 8 - Percentage loss of mass (hemicellulose e lignin) with application of chemical treatment

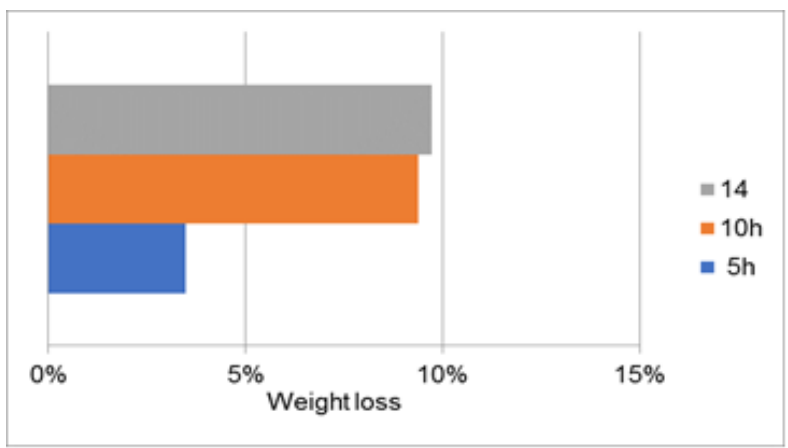

Source: Own authorship (2017)

According to Figure 8 it can be observed that as the exposure time of the fiber rises, there is an increase on the loss of mass level. This reduction is essential for some applications, where lower weight and volume is necessary.

\section{CHARACTERIZATION BY OPTICAL MICROSCOPY}

The Figure 9 (a) shows the micrograph, by optic microscopy, obtained from a cross-section of the fibers of bamboo in-natural after the drying process. It can be observed an increase of the gradient of concentration of the fibers. It can also be observed a darker region, composed by cellulose based tissue (sclerenchyma) and a lighter region that involves the fibrovascular strips, formed basically of lignin (parenchyma) (GHAVAMI, 2005; BRITO et al., 2015; RAY, 2004).

Figure 9 - Micrograph of the cross-section of bamboo, (a) details of the gradient of concentration, (b) medium fibers diameter.

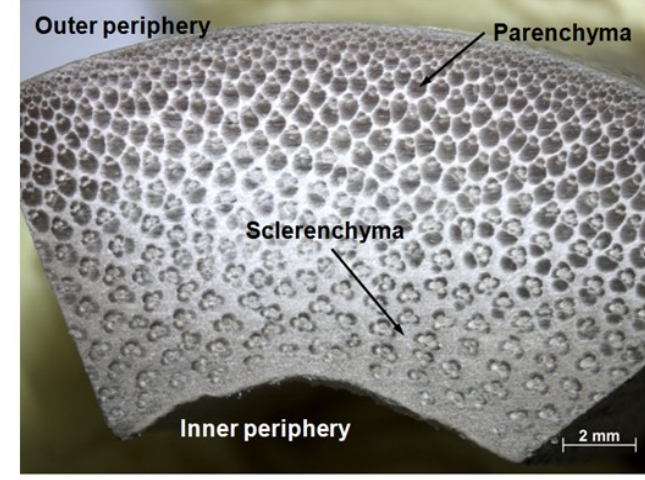

(a)

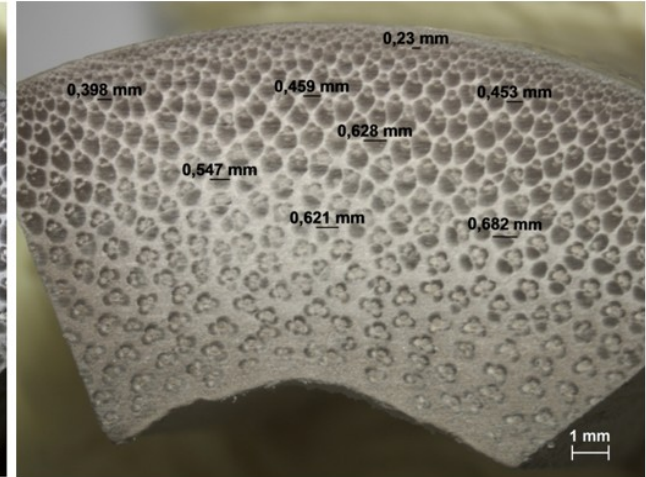

(b)

Source: Own authorship (2017) 
The population of fibers changes according to its position on the interior of the plant. On the external periphery, the fibers are compacter by nature, as they are higher in volume than fibers of the internal zone. The average diameter of these fibers is irregular and tends to decrease towards the external periphery of the plant, according to Figure 9 (b).

\section{CHARACTERIZATION BY SCANNING ELECTRON MICROSCOPY - SEM}

The micrographics obtained by SEM are shown on Figure 10, where it is presented the fiber in-natural (a) and a fiber treated with $\mathrm{NaOH}$ (b), it can be observed the principles of degradation due to the exposure to concentration of $\mathrm{NaOH}$. This is because of the removal of extracts, which make the fibers individualized.

The Figure 11 presents a wire of the fiber treated with $\mathrm{NaOH}$, followed by a detail where it was performed a section with a stiletto knife.

The Figure 12 presents the specter of chemical analysis performed by disperse energy spectroscopy. Traces of sodium are evident, because of the chemical treatment with $\mathrm{NaOH}$, as well as peaks of carbon and oxygen from the cellulose contents. The peak near $2,2 \mathrm{keV}(\mathrm{Au})$ is due to the coating used for specimens preparation.

Figure 10 - Micrographics of the bamboo fibers, (a) fiber in-natural, (b) fiber treated with $\mathrm{NaOH}$.

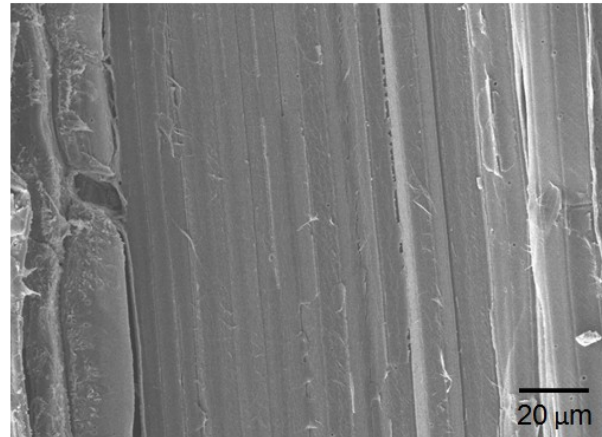

(a)

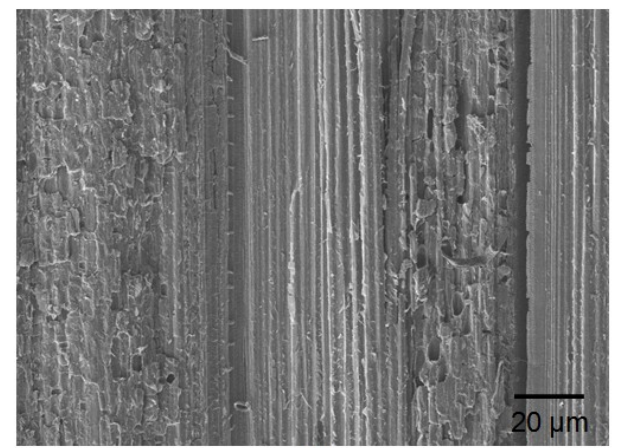

(b)

Source: Own authorship (2017)

Figure 11 - Wire of the fiber

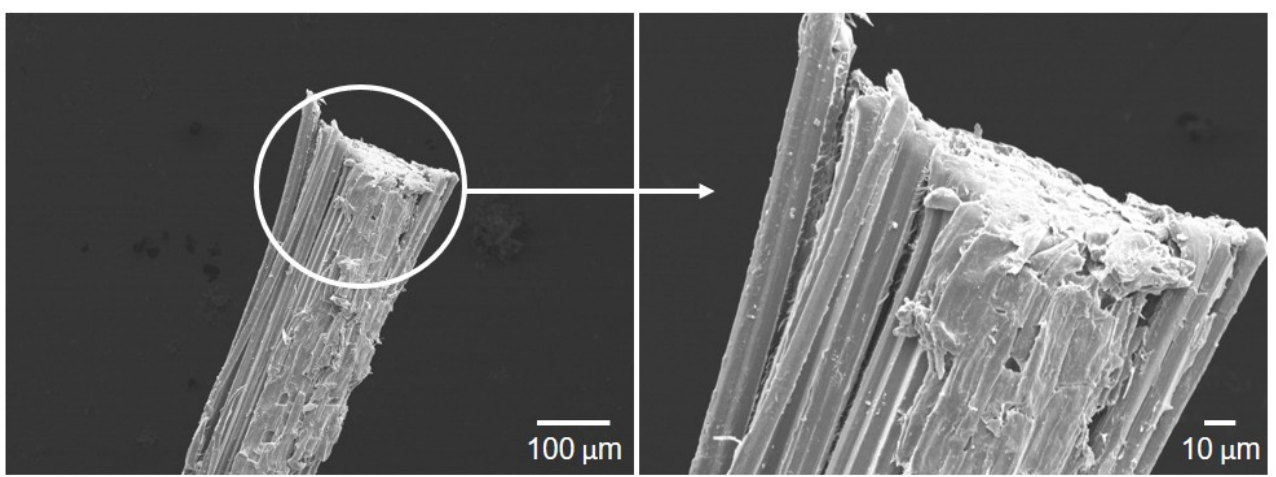

Source: Own authorship (2017). 
Figure 12 - Specter for chemical analysis

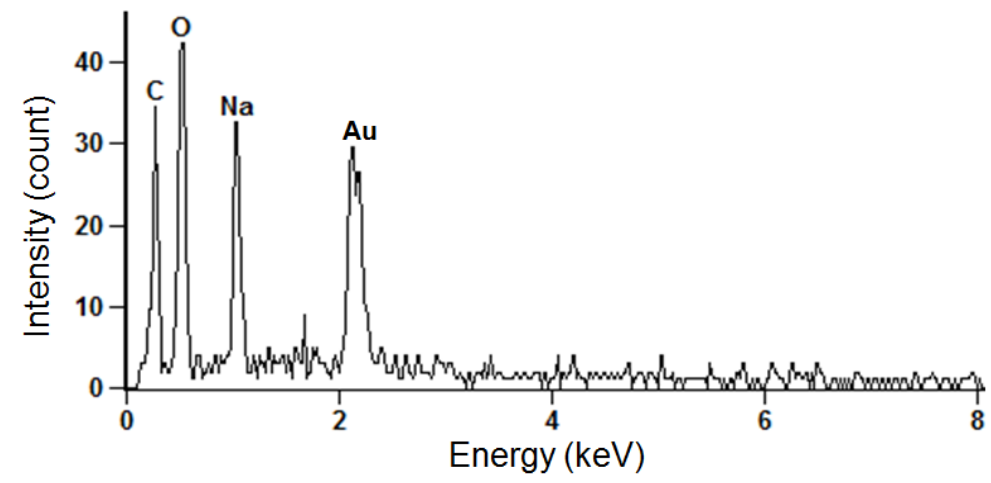

Source: Own authorship (2017).

The Table 3 presents the results of qualitative and semi-quantitative analysis, which reveal carbon as a major content element, while sodium is found in small amounts. This high percentage of carbon content is due to the chemical treatment with $\mathrm{NaOH}$, because of the elevation of cellulose content $\left(\mathrm{C}_{6} \mathrm{H}_{10} \mathrm{O}_{5}\right)$, which contributed to improve the properties of mechanical resistance of the fibers (JÄHN et al., 2002).

Table 3 - Results of the semi-quantitative analysis of the DES specter for the fiber treated with $\mathrm{NaOH} 1$

\begin{tabular}{cccccc} 
Element & Point 1 & Point 2 & Point 3 & Average & $\begin{array}{c}\text { Standard } \\
\text { deviation }\end{array}$ \\
$\mathrm{C}$ & $82,46 \pm 3,06$ & $86,82 \pm 2,99$ & $88,32 \pm 3,14$ & 85,87 & 3,04 \\
$\mathrm{O}$ & $4,53 \pm 0,24$ & $3,4 \pm 0,16$ & $3,1 \pm 0,11$ & 3,68 & 0,75 \\
$\mathrm{Na}$ & $13,01 \pm 2,31$ & $9,78 \pm 1,74$ & $8,66 \pm 1,93$ & 10,48 & 2,26 \\
\hline
\end{tabular}

Source: Own authorship (2017)

\section{BENDING TEST}

The Figure 13 presents the curve force/time obtained through the bending test on four points. It can be observed that the sample of fiber treated with $\mathrm{NaOH}$ supported the highest load value, reaching $13,49 \mathrm{kN}$, a value higher than the found on literature (OLIVEIRA, 2014). The fiber in-natural presented a value similar to the resistance obtained by the block reinforced with the steel rebar. All kinds of reinforcement used increased the resistance of concrete, this is evident once the curve of the block without reinforcement supported the lowest load value during the bending test.

It can be observed on the curve of Figure 13 that the concrete block reinforce with steel broke at around $10 \mathrm{kN}$, however the rebar continued providing resistance to the material, increasing the applied load. Differently from the blocks reinforced with bamboo fibers in-natural, which presented fragile fracture values and completely lost the resistance.

According to Figure 13, it can be observed that the block without reinforcement presented greater deformation, due to the ceramic characteristic of the material. The block with fiber in-natural presented the smallest 
deformation, characteristic of the fragile break of the bamboo fiber. The block reinforced with treated fibers had an increase on the deformation, when compared to the fiber in-natural, beyond the increase of the tensile strength on the bending.

Figure 13 - Curve of the tensile strength on bending test in four point

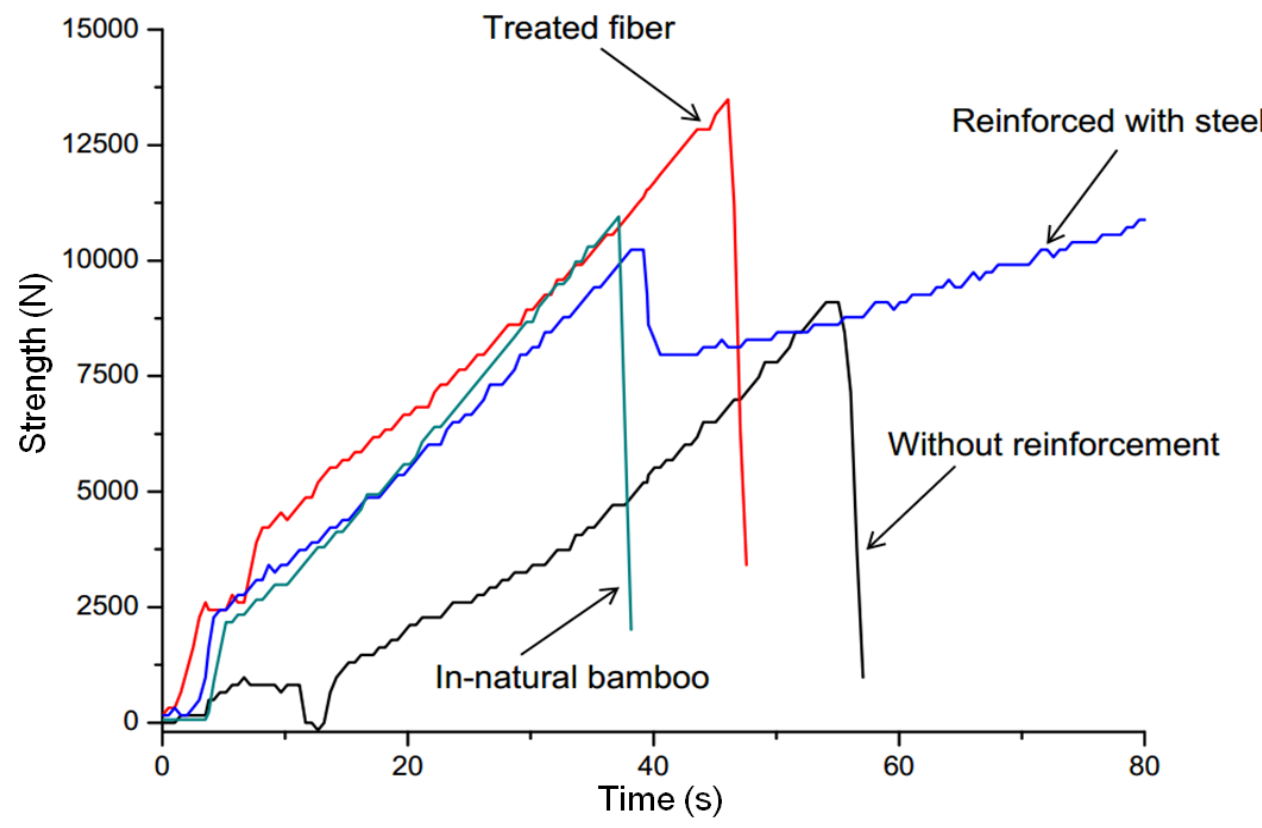

Source: Own authorship (2017)

The Table 4 presents the values of tensile strength for the used samples. For the block reinforced with steel the maximum stress was calculated on the moment of the concrete rupture, at 38,65 seconds.

Table 2 - Results of tensile strength on the bending of concrete prisms

\begin{tabular}{cccc}
$\begin{array}{c}\text { Max } \\
\text { Without reinforcement }\end{array}$ & 9,10 & 4,10 & $\begin{array}{c}\text { Rate } \\
\text { force. }(\mathrm{kN})\end{array}$ \\
$\begin{array}{c}\text { Max stress. (MPa) } \\
\text { Reinforced with in-natural bamboo }\end{array}$ & 10,95 & 4,93 & 4,60 \\
Reinforced with treated bamboo & 13,49 & 6,07 & 6,70 \\
Reinforced with steel & 10,24 & 4,61 & 7,80 \\
Average & 10,95 & 4,93 & 6,50 \\
\hline
\end{tabular}

Source: Own authorship (2017)

The Figure 14 presents the propagation of cracks on the blocks reinforced with chemically treated fibers (a) and with steel reinforcement (b). It can be observed that for the block reinforced with fibers treated with $\mathrm{NaOH}(\mathrm{a})$ the crack width was larger from the break moment, it occurs due to the fragile characteristic presented by the fiber. 
Figure 14 - Rupture of the block on the bending test (a) with treated fibers, (b) with steel reinforcement

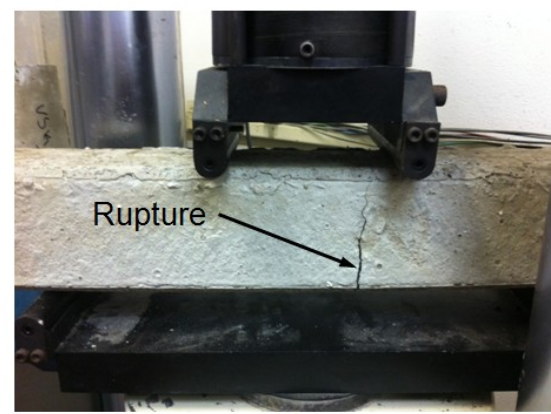

(a)

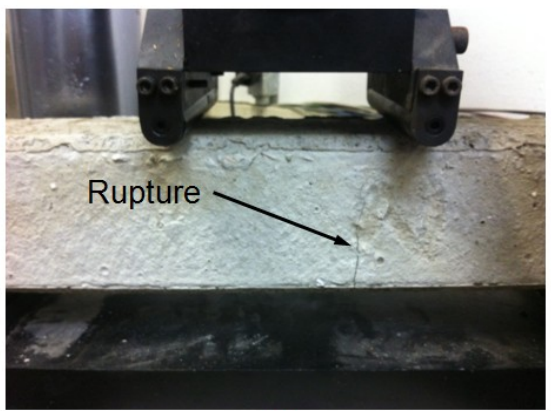

(b)

Source: Own authorship (2017)

The Table 5 presents a comparison between the characteristics of the two kinds of reinforcements used on the manufacturing of the composites and their respective contributions for the tensile strength on the bending. For comparison reasons, pieces with fibers of bamboo in-natural with a size proportional to the blocks have been used, totalizing a cross-section area of $240 \mathrm{~mm}^{2}$.

With the application of treatment on the bamboo fibers it was possible to reach a stress of $6,07 \mathrm{MPa}$ for a cross-section area of $113,10 \mathrm{~mm}^{2}, 46 \%$ smaller than that used on the block reinforced with bamboo in-natural. These values are below those found on the tensile strength of the wires due to discontinuing presented by the fiber bundle, as irregular diameter and failures on the its packing.

When using the steel rebar with ribbed surface for the block reinforcement, it was possible to reach a stress of $4,61 \mathrm{MPa}$, considering a cross-section area of $3,70 \mathrm{~mm}^{2}$. This value is lower than that obtained by the piece of bamboo innatural, which was 4,93MPa.

Table 3 - Comparative between reinforcements applied on concrete

\begin{tabular}{cccc} 
Specimen & $\begin{array}{c}\text { Max stress. } \\
(\mathrm{MPa})\end{array}$ & $\begin{array}{c}\text { Cross- } \\
\text { section area } \\
\left(\mathrm{mm}^{2}\right)\end{array}$ & $\begin{array}{c}\text { Reinforcement } \\
\text { mass }(\mathrm{g})\end{array}$ \\
$\begin{array}{c}\text { Without reinforcement } \\
\text { Reinforced with bamboo in-natural }\end{array}$ & 4,93 & - & - \\
Reinforced with treated bamboo & 6,07 & 210,00 & 51,20 \\
Reinforced with steel & 4,61 & 31,70 & 29,28 \\
\hline
\end{tabular}

Source: Own authorship (2017)

The Table 6 presents an estimative for the stress value, considering the same cross-section area for the three kinds of reinforcements used on the blocks (pieces of bamboo in-natural; treated fiber and steel rebar).

It can be noticed an increase of approximately $400 \mathrm{~g}$ on the mass of the reinforcement of steel rebar, in comparison to the reinforced with bamboo, what can be negative when a reduction on the structures weight is aimed. For the fiber treated it can be observed that for a cross-section area of $100 \mathrm{~mm}^{2}$ it has $25,88 \mathrm{~g}$ mass on the reinforcement, value similar to the obtained with bamboo in-natural, however with higher resistance. 
Table 4 - Estimative of stress for the same cross-section area

\begin{tabular}{lccc} 
Specimen & $\begin{array}{c}\text { Estimated } \\
\text { stress } \\
(\mathrm{MPa})\end{array}$ & $\begin{array}{c}\text { Cross-section } \\
\text { area }\left(\mathrm{mm}^{2}\right)\end{array}$ & $\begin{array}{c}\text { Reinforcement } \\
\text { mass (g) }\end{array}$ \\
Without reinforcement & 4,10 & - & - \\
Reinforced with bamboo in-natural & 4,10 & 100,00 & 24,38 \\
Reinforced with treated bamboo & 5,37 & 100,00 & 25,88 \\
Reinforced with steel & 14,54 & 100,00 & 428,23 \\
\hline
\end{tabular}

Source: Own authorship (2017)

\section{CONCLUSIONS}

This work it was performed chemical treatment with $\mathrm{NaOH}$ on bamboo fibers for application as a reinforcement of concrete blocks. The fibers have been characterized and the composite material was analyzed with tensile strength on bending tests. The study showed that the application of chemical treatment on the fibers can increase the property of mechanical resistance of concrete blocks.

The characterization performed by optical microscopy revealed an increase on the gradient of concentration of the fibers, as well as the regions composed by cellulose-based tissue (sclerenchyma) and regions formed by lignin (parenchyma).

The characterization performed by scanning electron microscopy showed principles of degradation generated by the exposure to concentration of $\mathrm{NaOH}$.

The chemical analysis performed, through DES, revealed peaks of $C$ and $O$ because of the organic materials presented on the fibers wall. The increase on carbon content with the application of chemical treatment with $\mathrm{NaOH}$ increased the content of cellulose, contributing to improve the properties of mechanical resistance of the fibers.

Through the bending test, it was possible to determine the contribution of the treated fibers reinforcement for the tensile strength on bending of the concrete blocks, evidencing the importance of the application of the chemical treatment process.

The study revealed that it is possible to use the bamboo fiber as an alternative for reinforcement, as a substitute of steel on concrete blocks manufacturing, with resistance superior to that of those reinforced with bamboo in-natural. The next step is to analyze the manufacturing costs for preparation of fibers treated with $\mathrm{NaOH}$ for application on cement material reinforcement, and to evaluate the lifetime of the treated fibers.

\section{ACKNOWLEDGEMENTS}

The authors gratefully acknowledge financial and technical support from Foundation Technological Institute of Joinville (FITEJ). And the company ENVILLE technology in constructions. 


\title{
Avaliação de blocos de concreto reforçados com fibras de bambu tratadas com $\mathrm{NaOH}$
}

\begin{abstract}
RESUMO
Este trabalho pesquisa a influência do tratamento químico de Hidróxido de Sódio $(\mathrm{NaOH})$ aplicado às fibras de bambu para utilização como reforço em blocos de concreto. O objetivo é analisar a influência das fibras nas propriedades mecânicas do compósito cimentício. A metodologia de pesquisa utilizada neste trabalho é de caráter literário e experimental, a planta investigada é da espécie Bambusa Vulgarise, que passou pelo tratamento químico com $\mathrm{NaOH}$. Posteriormente essas fibras foram caracterizadas por microscopia óptica e SEM. A caracterização do material compósito foi realizada através de ensaios de flexão. Os resultados mostram à contribuição do reforço de fibras tratadas na propriedade de resistência a tração na flexão dos blocos de concreto, evidenciando a importância da aplicação do tratamento químico. 0 estudo mostra que é possível utilizar a fibra de bambu tratada como alternativa viável no reforço de blocos de concreto, com resistência superior aos produzidos com bambu in-natura
\end{abstract}

PALAVRAS-CHAVE: Fibra de bambu. Tratamento químico. Blocos de concreto. $\mathrm{NaOH}$ 


\section{REFERENCES}

ABNT - Associação brasileira de normas técnicas. NBR - 12142. Concreto Determinação da resistência à tração na flexão de corpos de prova prismáticos. Rio de Janeiro, 2010 (in Portuguese).

ABNT - Associação brasileira de normas técnicas. NBR 14931. Execução de estruturas de concreto. Rio de Janeiro, 2004 (in Portuguese).

BRITO, F.M.; PAES, J.B.; OLIVEIRA, J.T.S.; ARANTES, M.D.C.; NETO, H.F. Caracterização Anatômica e Física do Bambu Gigante (Dendrocalamus giganteus Munro). Floresta Ambient, 2015; 22(4): 559-566 (in Portuguese). crossref

DAS, M.; CHAKRABORTY, D. Evaluation of improvement of physical and mechanical properties of bamboo fibres due to alkali treatment. Journal of Applied Polymer Science, 107(1), 2008, pp 522-527. crossref

GHAVAMI K. Bamboo as reinforcement in structural concrete elements. In: Cement \& concrete composites, 2005;27: 637-649. crossref

GHAVAMI, K. Ultimate load behaviour of bamboo-reinforced lightweight concrete beams. Cement and Concrete Composites, London, 1995;17(4): 259351. crossref

GHAVAMI, K.; BARBOSA, N.P. Bambu. In: ISAIA, G. C. (Org./Ed.). Materiais de Construção Civil e Princípios de Ciências e Engenharia de Materiais. São Paulo: IBRACON, 2007; 1559-1589 (in Portuguese).

GHAVAMI, K.; MARINHO, A.B. Propriedades físicas e mecânicas do colmo inteiro do bambu da espécie Guadua angustifólia. Revista Brasileira de Engenharia Agrícola e Ambiental, 2005;9(1): 107-114 (in Portuguese). crossref

JÄHN, A.; SCHRÖDER, M.W.; FÜTING, B.; SCHENZEL, K.; DIEPENBROCK, W. Characterization of alkali treated flax fibres by means of FT Raman spectroscopy and environmental scanning electron microscopy. Spectrochim Acta A Mol Biomol Spectrosc. 2002 Aug;58(10): 2271-9. crossref

KONGKEAW, P.; NHUAPENG, W.; THAMAJAREE, W. The effect of fiber length on tensile properties of epoxy resin composites reinforced by the fibers of bamboo (Thyrsostachys Siamensis Gamble). Journal of the Microscopy Society of Thailand, v. 2011; 46-48. 
KUMAR, S.; CHOUDHARY, V.; KUMAR, R.J. Study on the compatibility of unbleached and bleached bamboo-fiber with LLDPE matrix. Therm Anal Calorim (2010) 102: 751. crossref

LI, T.; CHENG, D.; WÅLINDER, M.E.P.; ZHOU, D. Wettability of oil heat-reated bamboo and bonding strength of laminated bamboo board. Industrial Crops and Products. Elsevier, v. 1. 2015; (69): 15-20.

LIU, D.; SONG, J.; ANDERSON, D.P.; CHANG, P.R.; HUA, Y. Bamboo Fiber and its Reinforced Composites: Structure and Properties. Cellulose. 2012; 19(5):144980. crossref

LIU, D.; ZHONG, T.; CHANG, P.R.; LI, K.; WU, Q. Starch composites reinforced by bamboo cellulosic crystals. Bioresource Technol. 2010, 101, 2529-2536. crossref

OLIVEIRA, C.A.S.; GOUVEIA, L.L.A.; TEIXEIRA, R.L.P. Concreto estrutural com adição de fibras vegetais. Construindo, Belo Horizonte 2014;6(2): 14-19 (in Portuguese).

PHILIPP, P.; D’ALMEIDA, M.L.O. Celulose papel: Tecnologia de fabricação da pasta celulose. São Paulo 2a Ed., IPT., v1. 1998, pp. 48 (in Portuguese).

RAY, A.K.; DAS, S.K.; MONDAL, S. Microstructural characterization of bamboo. Journal of Materials Science 2004; 39: 1055 - 1060. crossref

SHARMA, B.; GATÓO, A.; BOCK, M.; MULLIGAN, H.; RAMAGE, M. Engineered bamboo for structural applications. Construction and Building Materials 2015;81: 66-73. crossref

SHARMA, B.; GATÓO, A.; RAMAGE, M.H. Effect of processing methods on the mechanical properties of engineered bamboo. Construction and Building Materials 83 (2015) 95-101. crossref

TRUJILLO, E.; OSORIO, L.; VAN VUURE, A.W.; LENS, F.; IVENS, J.; VERPOEST, I. The relation between bamboo fibre microstructure and mechanical properties.

ECCM 14 European Conference on Composite Materials, Budapest, Hungary June 7-10 2010.

XIE, X.; ZHOU, Z.; JIANG, M.; XU, X.; WANG, Z.; HUI, D. Cellulosic fibers from rice straw and bamboo used as reinforcement of cement-based composites for remarkably improving mechanical properties. Composites Part B. Elsevier 2015;78:153-161. crossref 
YU, Y.; WANG, H.; LU, F.; TIAN, G.; LIN, J. Bamboo fibers for composite applications: a mechanical and morphological investigation. J Mater Sci. (2013) 49: 2559-66. crossref

Recebido: 05 dez. 2017

Aprovado: 04 jun. 2018

DOI: 10.3895/gi.v14n3.7476

Como citar:

MOURA, C. R.; VALENTINA, L. V. O. D.; VIEIRA, A. J. T. Evaluation of concrete blocks reinforced with bamboo fibers treated with NaOH. R. Gest. Industr., Ponta Grossa, v. 14, n. 3, p. 191-208, jul./set. 2018. Disponivel em: <https://periodicos.utfpr.edu.br/rgi . Acesso em: XXX.

Correspondência:

Cassiano Rodrigues Moura

Rua dos Imigrantes, 445, Rau, Jaraguá do Sul, Santa Catarina, Brasil.

Direito autoral: Este artigo está licenciado sob os termos da Licença Creative Commons-Atribuição 4.0 Internacional.

\section{(c) (1)}

